\title{
Habitat Selection and Mating Success in a Mustelid
}

\author{
Thierry Lodé \\ UMR CNRS 6552 ETHOS, Université de Rennes 1, 35042 Rennes, France \\ Correspondence should be addressed to Thierry Lodé, thierry.lode@univ-rennes1.fr
}

Received 4 December 2010; Revised 20 February 2011; Accepted 4 March 2011

Academic Editor: Hynek Burda

Copyright (C) 2011 Thierry Lodé. This is an open access article distributed under the Creative Commons Attribution License, which permits unrestricted use, distribution, and reproduction in any medium, provided the original work is properly cited.

\begin{abstract}
Habitat selection remains a poorly understood ecological process, but relating mating behaviour to pattern of habitat selection constitutes a fundamental issue both in evolutionary ecology and in biological conservation. From radiotelemetry protocol, habitat-induced variations in mating success were investigated in a solitary mustelid carnivore, the European polecat Mustela putorius. Selection for marshy habitat was regarded as adaptive in that mating success was found greater using marches than other habitats. Males consorted with 1.3 females, revealing a low polygyny rate. Pregnant or lactating females selectively shifted to deciduous woods. That some habitat types may favour a good reproduction forms a key factor for species conservation and environmental management. Nevertheless, such as in various vertebrates, habitat requirements seem to be based on simple broad features of habitat, suggesting that habitat avoidance rather than habitat preference can explain polecat habitat predilection.
\end{abstract}

\section{Introduction}

Adaptive significance of a behaviour is recognized when a behaviour provides a selective advantage in animal ability to adapt to its environment. Landscape structures are expected to influence especially mating behaviour and numerous species required heterogeneous habitat composition.

Differences in habitat use among animals have been often ascribed to habitat selection although habitat selection remained a poorly known behavioural ecological process [13]. Patterns of habitat use may reveal specific choice for habitat, which should provide numerous benefits such as resource availability, shelter, avoidance of predation, and reduced interspecific competition $[4,5]$. The basic conjecture in habitat selection theory is that animals select habitat features to maximize their fitness [6-9]. Thus, habitat selection is a behaviour related to fitness and differs from habitat use in which habitat preferences are mainly linked to resources. Habitat selection can lead to a strong fidelity to habitat features in which fitness was previously high [10].

Numerous species showed partitioning in microhabitat preferences, but patent demonstration for habitat selection was rare $[11,12]$. Actually, natural selection can occur when distinct habitat types differ in successful breeding, and putative differences between unsuccessful and successful reproductive sites can be regarded as reflecting habitat selection $[8,12,13]$. It could be predicted that no selection occurs when unsuccessful and successful reproductive sites are not discernible from most of their main habitat features, but McLoughlin et al. [12] found no variations at the homerange level but differences within the home range level underline the importance of spatial scale dependence in habitat selection $[6,14]$.

Selection of better reproductive sites and habitat features should be indicative of adaptive behavioural preferences but can often result in increasing competition, habitat selectivity, and declining population density [4]. Habitat selection and nest-sites choice have been widely studied in birds although differences in fitness were not often examined $[8,15,16]$. However, differences in habitat can have noticeable effects on reproduction [9]. The relationship between male status and mating success was reported from social mammals such as mongooses and badgers [17-19], but numerous species lived a solitary life, and their social organisation was mainly based on spatial pattern [20]. This is especially the case for most carnivores, and although habitat features have been recognized as major parameters for species conservation (see [21]), the role of habitat selection has still received little attention. 
In solitary carnivores, male and female live independently over long periods and generally exhibit a mating system in which the male home range partially overlaps the range of one or several females [22-25]. Because carnivores were routine and did not try to avoid poor environmental conditions, it could be predicted that habitat traits have a major influence on their mating success.

This study investigates the role of habitat selection on the mating success of a solitary mustelid carnivore, the European polecat Mustela putorius. Based on a long-term survey of radiotracked animals, this study aims at characterising habitat features and mating success to assess whether habitat features may affect mating success (habitat selection).

\section{Methods}

Radiotracked polecats (24 males and 25 females, 19922002) were mainly surveyed from winter to spring in Western France (Brière $47^{\circ} 20^{\prime} \mathrm{N}, 2^{\circ} 10^{\prime} \mathrm{W}$, lake of GrandLieu and Tenu river $47^{\circ} 05^{\prime} \mathrm{N}, 1^{\circ} 39^{\prime} \mathrm{W}$ ), and data from each individual was only used once. The climate of an oceanic type is mild and humid (mean temperature August $20^{\circ} \mathrm{C}$, and mean temperature February $5^{\circ} \mathrm{C}$, annual precipitation $650 \mathrm{~mm}$, with about 2 snowy days per year). Every animal was surveyed 121-223 days, but numerous individuals were recaptured several times. From a capture-recapture design, density estimates were regarded as moderately high ranging from 0.35 to 0.57 individuals per $\mathrm{km}^{2}$ in 2002 .

The consortship behaviour consists of a brief association between an adult male and an adult female, showing activity within the same restricted area and often resting together in the same den during oestrus [26, 27]. Consortship success was determined by trapping, incidental observations (using night vision optics NONH4U), and radiotracking locations. Throughout the reproductive season, trapping sessions were repeatedly conducted using 20 box-traps in every studied site in order to detect the presence of other individuals during the mating season. Polecats are usually intolerant towards any congeners, exhibiting a strong individual segregation in the use of space, and associations between individuals are restricted to the breeding period [24, 28, 29]. Because copulation induces ovulation, breeding success depends upon the male tenacity, and most of recaptured females exhibited scratches on the neck and on the back resulting from the copulation, when the male remained on the female with a bite often lasting more than one hour [27]. Therefore, the consortship behaviour provides a good indication of the mating activity [26] although how consortship behaviour is related to breeding success remains unknown. Most of copulations occurred before Apri, and parturitions, as revealed by recaptures of lactating females, occurred from May to June.

A consortship was regarded as successful when it has occurred about 42 days (gestation duration) before the estimated date of parturitions. On a basis of a minimum of six consecutive fixes per day, the minimal consortship duration was assessed as a number of days during which male and female were diurnally associated in the den. For data from radiotracked polecats, we calculated the centre of activity (arithmetic mean) from fixes, and the minimal dispersal distance was assessed comparing minimal distance between telemetry locations.

Habitat use was inferred in male and female radiotracked polecats based on percentage of fixes found in a considered habitat type and was assigned to two main periods, winter (November-January) and breeding period (February-April for males, and May-June for females, because mating sites may differ with breeding sites in which parturitions occurred). Field study for determining habitat features was performed between July and September from 1998 to 2002, considering the minimum convex polygon of each individual and, for random sites, a number of putative locations, on the basis of average number of real fixes recorded, randomly assigned within the study areas.

We defined 19 habitat features as deciduous wood, oak grove, chestnut grove, hybrid poplar plantation, orchard and garden, willow grove, flooded herbaceous cover, reed-bed, ditches, river bank and riparian habitat, pond, grassland, pasture, cultivation and vineyard, shrub of bramble, hedges, road and path, barn and abandoned house, and at last farm and houses. Habitat diversity was assessed by the index $E=$ $A-1 / S-1$, where $A=1 / \sum P i^{2}[30]$ and $S$ is the total number of habitat type, considering only 6 major habitat types. An analysis of variance was used to investigate differences in habitat features among male sites considering male sites with consortship success, unconsorted male sites, and random sites. Because all females consorted, we only discriminated between habitat use from February to April (mating period) and from April to June (period of parturition). Paired $t$-test (with Bonferroni adjustment procedure) or Welch alternate $t$-test is used according to the case.

\section{Results}

3.1. Consortship Success. Moving across several female contiguous ranges, most male polecats $(80 \%, n=19 / 24)$ obtained brief consortships averaging 3.11 days $(\mathrm{sd}=1.26$, range $1-6$ days, and $n=19$ males). Males consorted with 1.33 partners ( $\mathrm{sd}=0.82, n=24$ males). All females consorted with at least one male and obtained a mean of 1.12 consortships ( $\mathrm{sd}=0.33, n=25$ females; Table 1 ). The consortship success was related to the consortship duration $\left(r_{\text {Spearman }}=0.705, P<.0001\right.$, and $\left.n=25\right)$. While consortship patterns in males characterised a polygynous mating system with a single male consorting with one to three females, some females were regarded as polyandrous.

3.2. Habitat Selection. During breeding period, polecats mainly used marshes and wooded areas, but habitat use differed between the sexes, females occupying significantly more woods and hedges, while males exploited mainly marshes $\left(\chi^{2}=42.3, P<.0001, d f=4\right)$ (Figure 1$)$.

Actually, habitat preferences seemed to be only based on superficial features of habitat, and marshy habitat features and deciduous woods appeared as the most important descriptors of polecat habitat. Habitat use in males was 
TABLE 1: Consortship duration and consortship success (number of sexual partners) for 24 radiotracked males and 25 females of European polecats Mustela putorius from Western France.

\begin{tabular}{|c|c|c|c|c|c|}
\hline & Males & $\begin{array}{l}\text { Number } \\
\text { of } \\
\text { sexual } \\
\text { partners }\end{array}$ & $\begin{array}{l}\text { Successful } \\
\text { Con- } \\
\text { sortship } \\
\text { with }\end{array}$ & $\begin{array}{l}\text { Number of } \\
\text { sexual } \\
\text { partners- } \\
\text { for } \\
\text { female }\end{array}$ & $\begin{array}{l}\text { Consortship } \\
\text { duration } \\
\text { (days) }\end{array}$ \\
\hline \multirow{34}{*}{$\begin{array}{l}\text { Breeding } \\
\text { males }\end{array}$} & M1 & 1 & F1 & 1 & 4 \\
\hline & M2 & 1 & $\mathrm{~F} 2$ & 1 & 3 \\
\hline & M3 & 1 & F3 & 1 & 4 \\
\hline & M4 & 2 & $\mathrm{~F} 4$ & 1 & 2 \\
\hline & & & F5 & 1 & 1 \\
\hline & M5 & 1 & F6 & 1 & 1 \\
\hline & M6 & 2 & F7 & 1 & 5 \\
\hline & & & F8 & 1 & 2 \\
\hline & M7 & 1 & F9 & 2 & 1 \\
\hline & M8 & 1 & F10 & 1 & 6 \\
\hline & M9 & 3 & F11 & 2 & 3 \\
\hline & & & F12 & 2 & 3 \\
\hline & & & F13 & 1 & 2 \\
\hline & M10 & 2 & F14 & 1 & 3 \\
\hline & & & F15 & 1 & 3 \\
\hline & M11 & 2 & F16 & 1 & 4 \\
\hline & & & F17 & 1 & 3 \\
\hline & M12 & 1 & F18 & 1 & 5 \\
\hline & M13 & 2 & F19 & 1 & 3 \\
\hline & & & F20 & 1 & 4 \\
\hline & M14 & 2 & $\mathrm{~F} 21$ & 1 & 5 \\
\hline & & & F22 & 1 & 3 \\
\hline & M15 & 2 & F23 & 1 & 3 \\
\hline & & & F24 & 1 & 3 \\
\hline & M16 & 1 & F25 & 1 & 4 \\
\hline & M17 & 1 & F17 & 1 & 2 \\
\hline & M18 & 1 & F18 & 1 & 3 \\
\hline & M19 & 1 & F20 & 1 & 2 \\
\hline & M20 & 0 & & & 0 \\
\hline & M21 & 0 & & & 0 \\
\hline & M22 & 0 & & & 0 \\
\hline & M23 & 0 & & & 0 \\
\hline & M24 & 0 & & & 0 \\
\hline & & $\begin{array}{c}\text { Mean }= \\
1.33\end{array}$ & & $\begin{array}{c}\text { Mean }= \\
1.12\end{array}$ & Mean $=2.33$ \\
\hline
\end{tabular}

chiefly influenced by willows, reedbeds, flooded herbaceous cover, and ditches, and in females, the choice of parturition sites was mainly influenced by ashes, oaks, willows, and reedbeds.

Nonetheless, evidence of habitat selection was found when differences among habitats, respectively, used by polecats, and habitats in random sites were tested with ANOVA (Table 2). In male polecats, marshy areas were the dominant habitat type, while meadows and various cultivations were

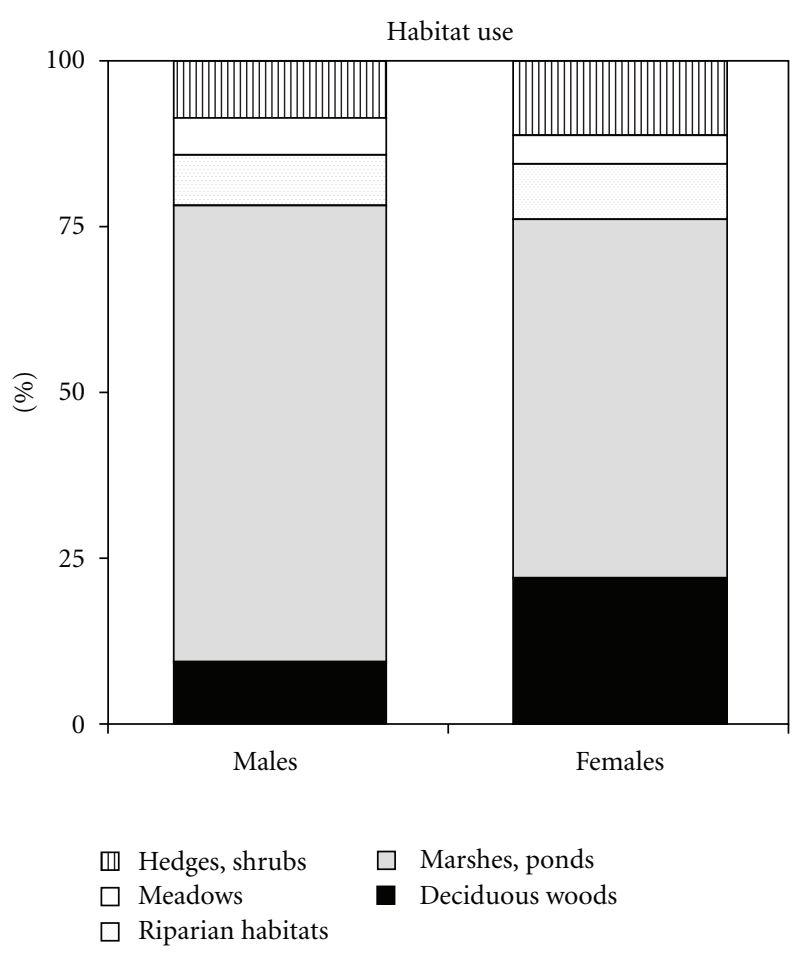

Figure 1: Habitat use in male and female radiotracked polecats based on percentage of fixes found in a considered habitat.

TABle 2: Differences among habitats used by 24 male and 25 female polecats and random sites (Anova from radiotracking locations, significant $P$ value in bold).

\begin{tabular}{lcccc}
\hline & $\begin{array}{c}\text { Mean } \\
\text { square }\end{array}$ & $\begin{array}{c}\text { Degree of } \\
\text { freedom }\end{array}$ & $\begin{array}{c}\text { Fisher } \\
\text { F }\end{array}$ & $P$ \\
\hline Males & & & & \\
$\quad$ Deciduous woods & 0.0019 & 1,39 & 0.87 & .358 \\
Marshy areas & 0.429 & 1,39 & 69.25 & $\mathbf{. 0 0 0 1}$ \\
Riparian habitat & 0.0033 & 1,39 & 2.47 & 0.125 \\
Meadows and cultivation & 0.523 & 1,39 & 104.38 & $\mathbf{. 0 0 0 1}$ \\
Hedges and shrubs & 0.021 & 1,39 & 12.42 & $\mathbf{. 0 0 1 1}$ \\
Females & & & & \\
Deciduous woods & 0.102 & 1,39 & 16.38 & $\mathbf{. 0 0 0 1}$ \\
Marshy areas & 0.114 & 1,39 & 18.39 & $\mathbf{. 0 0 0 1}$ \\
Riparian habitat & 0.0026 & 1,39 & 0.99 & .325 \\
Meadows and cultivation & 0.715 & 1,39 & 175.6 & $\mathbf{. 0 0 0 1}$ \\
Hedges and shrubs & 0.056 & 1,39 & 28.9 & $\mathbf{. 0 0 0 1}$ \\
\hline
\end{tabular}

deserted. Moreover, polecats used significantly more shrubs and hedges than other habitats. Female polecats were very selective in their habitat preferences using significantly more deciduous woods, hedges and shrubs, and marshy areas than randomly estimated, and they poorly utilised meadows and cultivation.

Furthermore, habitat use differences were found according to the consortship success (Figure 2), unconsorted male polecats using significantly more deciduous woods and less marshy areas than consorted polecats (Table 3). Because all 


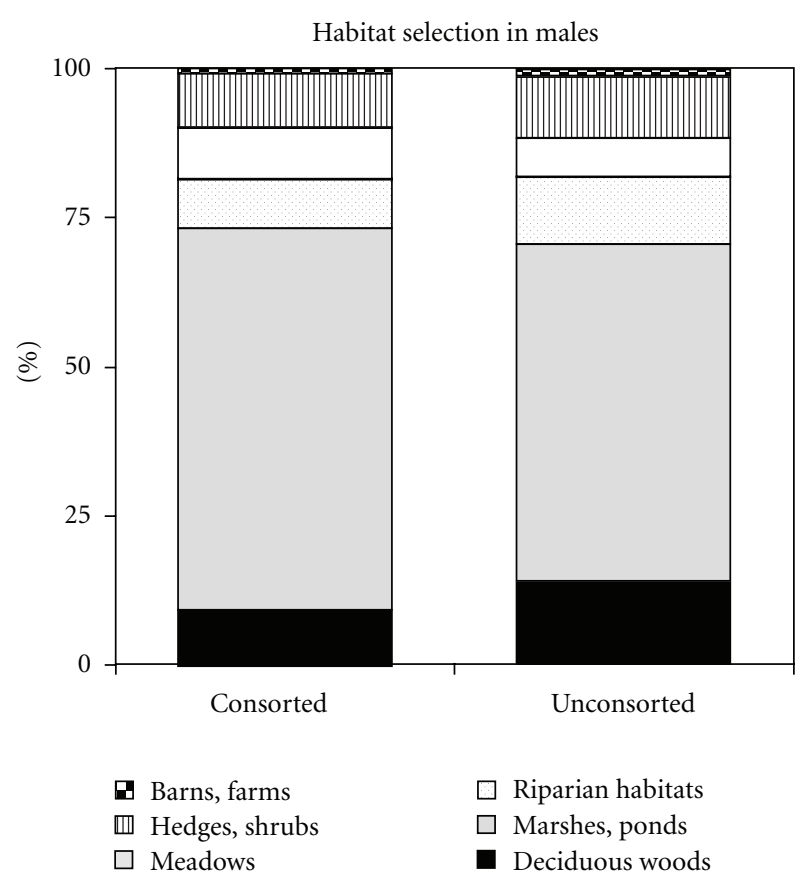

FIGURE 2: Habitat selection according to the consortship success of radiotracked male polecats. ( $n=19$ consorted polecats and $n=5$ unconsorted polecats) as revealed by percentage of fixes recorded in a considered habitat.

TABLE 3: Differences among habitat used by consorted $(n=19)$ and nonconsorted males $(n=5)$ (Anova from radiotracking locations, significant $P$ value in bold).

\begin{tabular}{lcccc}
\hline Males & $\begin{array}{c}\text { Mean } \\
\text { square }\end{array}$ & $\begin{array}{c}\text { Degree of } \\
\text { freedom }\end{array}$ & Fisher & $P$ \\
\hline Deciduous woods & 0.089 & 1,23 & 4.68 & $\mathbf{. 0 4 2}$ \\
Marshy areas & 0.022 & 1,23 & 5.03 & $\mathbf{. 0 3 5}$ \\
Riparian habitat & 0.034 & 1,23 & 2.05 & .166 \\
Meadows and cultivation & 0.018 & 1,23 & 0.95 & .338 \\
Hedges and shrubs & 0.0008 & 1,23 & 0.34 & .564 \\
\hline
\end{tabular}

surveyed female polecats consorted and bred successfully, it was impossible to run a same analysis. Nevertheless, pregnant or lactating females settled in distinct areas in MayJune switching for more woody habitats (paired $t$-test $=6.28$, $P<.0001$, and $d f=23$, Figure 3 ) and riparian habitats (paired $t$-test $=2.31, P=.03$, and $d f=23$ ) whereas the use of marshy areas decreased (paired $t$-test $=9.57, P<.0001$, and $d f=23$ ). The use of shrubs and hedges increased (paired $t$-test $=3.58, P<.002$, and $d f=23$ ) probably related to the search for a quiet parturition place. The index of habitat diversity significantly differed between space used by consorted polecats $(E=0.225, \mathrm{sd}=0.062)$ and random sites $(0.428$, sd $=0.087)($ Welch $T$-test $=11.2, P<.0001$, $d f=53)$.

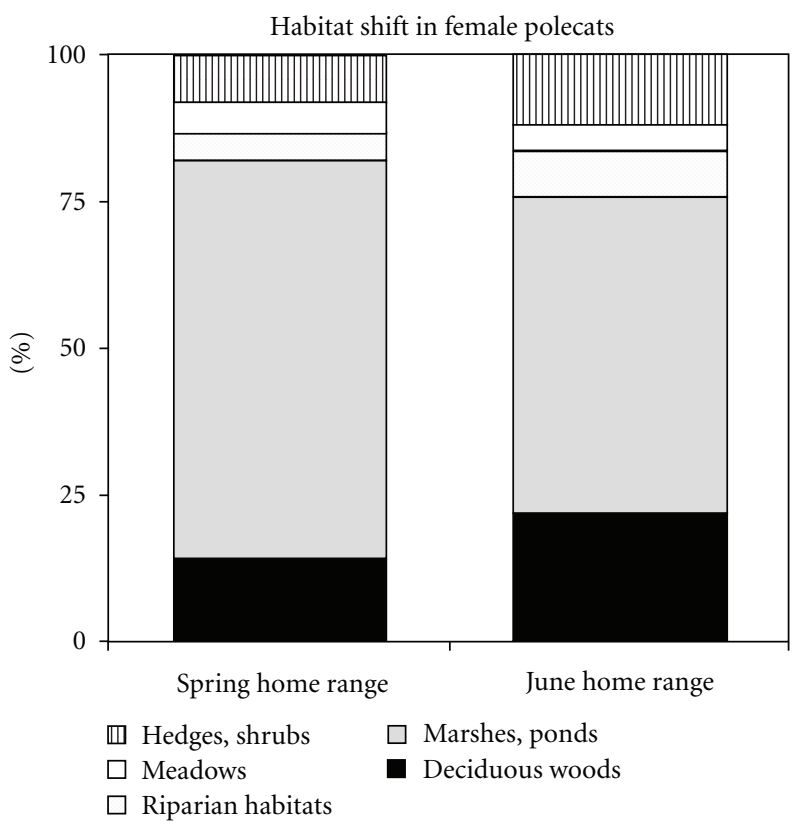

Figure 3: Habitat shift in surveyed female polecats from March (consortship sites) to June (parturition sites) as revealed by percentage of fixes recorded in a considered habitat.

\section{Discussion}

Polecats shifted for marshy and wooded areas during their breeding period, but many habitat features did not clearly differ from random sites with regard to most of their characteristics.

Studies of animal distribution in habitats often dealt with habitat preferences with no assessment of mating success or remained mainly based on indirect approach such as variations in density or abundance $[3,15,31,32]$. Such approaches described habitat features, which could be poorly related to fitness but rather with resource availability [8]. Measurement of habitat features, which were directly associated with breeding activities such as nesting, should more reflect habitat selection $[8,13,33,34]$.

Habitat features associated with consortship success should at least indirectly reflect features that affect fitness. Mating sites differed from random sites only in some rough habitat features, and characteristics of successful mating sites have uncertain ecological meaning. Three nonexclusive causes could be evoked for such findings. Firstly, it may be alleged that every habitat type induces few differences in fitness, and thus, further habitat selection does not occur in polecat. Secondly, habitat use can be regarded as a result of limited opportunities for animals to optimise when preferred habitats are saturated. Thirdly, searching for the preferred habitat may result in a relatively low benefit.

Because habitats features differed between random sites and mating sites, it should be recognised that polecats exhibited at least a slight selection for habitat. Diversity of habitat used by breeding polecat differed significantly from random sites, revealing that certain habitat were less occupied during reproduction. Nevertheless, it could be 
suspected that low benefits in mating success resulted from habitat selection. Habitat requirements of most vertebrates seem to be based on simple superficial features of habitat [21, 34-38]. Thus, the stone marten exhibited a preference for "stony" environment and regardless of other habitat features inhabited deciduous woods as well as barns, farms, or buildings in towns [25,39].

Following Haila et al. [35], it may be suggested that habitat avoidance rather than habitat preference can explain such predilection. Polecats were found to avoid open meadows and cultivation and seemed to prefer high vegetation cover or undisturbed areas. Polecats showed very secretive movements in shrubs and along hedges, resting in dense vegetation, in burrows or warrens. Habitats were selectively exploited, and while polecats often moved sheltered by hedges and shrubs, most open environments were deserted. The use of bramble patches is regarded as a need for protection against predators [40]. Woods, hedges, and shrubs may ensure more protected movements [41], and most mustelids were also known to avoid openfields [40, 42, 43]. Moreover, as reproductive activity resulting in a reduced vigilance, mating may be affected by the existence of refuges.

At the broader scale of habitat selection, some factors, chiefly marshy and wooded habitats, were found to influence mating success. Although some carnivores could be thought as habitat generalists, habitat definition has been recognised as scale dependent $[14,44]$. Thus, successfully consorted polecats significantly used more marshes and were found less frequently in deciduous woods than unconsorted males, whereas pregnant or lactating females increased their use of wooded areas.

Habitat preferences identified for polecat males were clearly adaptive in that mating success was greater using more marshy areas than other habitats, but the reason why mating success was associated with such broad habitat features remains unclear. Marshes consisted of heterogeneous vegetation cover but were seldom used by other carnivores. Marshy areas may be regarded as preferred habitat, and polecats were found to competitively exploit a specific habitat niche. The influence of trophic availability on habitat selection patterns cannot be ruled out $[45,46]$, but, as most animals, when polecats searched for mates, they considerably reduced their feeding activities. Finally, the link between the genetic divergence within polecat populations and polecat partitioning for habitat [47] supports the adaptive significance of habitat preference.

Polecats were selective in habitat use and exhibited a strong sexual segregation both in the use of space and in the activity rhythms [24], with females avoiding male-occupied zones and displaying cautiousness towards their unfamiliar conspecifics. Female avoidance from male ranges may be related to the need of protection for offspring [24]. Additionally, this spatial pattern may reflect a segregation limiting ecological competition [46]. Such reduced overlap was also observed in other carnivores such as the skunk [48]. Similarly, in grizzly bear, females with cubs tended to avoid habitat used by males throughout the year [12, 49].

The polecat mating system was characterised by a successive polygynous strategy, but averaging only 1.6 females per male, the polygyny rate appeared very low. Because polecats assiduously exploited some patchy area until resource depletion, solitary habits were basically proved to be adaptive $[24,46,50]$. Conversely, such habits result in a low polygyny rate, suggesting an evolutionary cost induced by this specific spatial pattern.

Anyway, that certain habitat features favour a best mating success constitutes a key factor for polecat conservation and environmental management.

\section{Acknowledgments}

The author thanks all his assistants for help in collecting the field data and especially Y. Benoit, Y. Biraud, H. Brault, F. Cupertino, R. Dagault, F. Dussault, A. Pihuit, M. Pondaven, and J. Y. Robert. Thanks are also due to D. Le Jacques.

\section{References}

[1] R. E. Ricklefs, Ecology, W.H. Freeman, New York, NY, USA, 1990.

[2] C. J. Krebs, Ecology, The Experimental Analysis of Distribution and Abundance, Harper Collins College, Glenview, Ill, USA, 4th edition, 1994.

[3] J. A. F. Diniz-Filho, L. M. Bini, M. Á. Rodríguez, T. F. L. V. B. Rangel, and B. A. Hawkins, "Seeing the forest for the trees: partitioning ecological and phylogenetic components of Bergmann's rule in European Carnivora," Ecography, vol. 30, no. 4, pp. 598-608, 2007.

[4] M. L. Rosenzweig, "Habitat selection and population interactions: the search for mechanism," American Naturalist, vol. 137, pp. S5-S28, 1991.

[5] Z. Abramsky, M. L. Rosenzweig, and A. Subach, "Measuring the benefit of habitat selection," Behavioral Ecology, vol. 13, no. 4, pp. 497-502, 2002.

[6] D. W. Morris, "Scales and costs of habitat selection in heterogeneous landscapes," Evolutionary Ecology, vol. 6, no. 5, pp. 412-432, 1992.

[7] M. L. Rosenzweig, Species Diversity in Time and Space, Cambridge University Press, Cambridge, UK, 1996.

[8] T. E. Martin, "Are microhabitat preferences of coexisting species under selection and adaptive?" Ecology, vol. 79, no. 2, pp. 656-670, 1998.

[9] D. R. Rubenstein, "Territory quality drives intraspecific patterns of extrapair paternity," Behavioral Ecology, vol. 18, no. 6, pp. 1058-1064, 2007.

[10] P. V. Switzer, "Past reproductive success affects future habitat selection," Behavioral Ecology and Sociobiology, vol. 40, no. 5, pp. 307-312, 1997.

[11] J. J. Jaenike and R. D. Holt, "Genetic variation for habitat preference: evidence and explanations," American Naturalist, vol. 137, pp. S67-S90, 1991.

[12] P. D. McLoughlin, R. L. Case, R. J. Gau, H. D. Cluff, R. Mulders, and F. Messier, "Hierarchical habitat selection by barren-ground grizzly bears in the central Canadian Arctic," Oecologia, vol. 132, no. 1, pp. 102-108, 2002.

[13] T. F. Haensly, J. A. Crawford, and S. M. Meyers, "Relationships of habitat structure to nest success of ring-necked pheasants," Journal of Wildlife Management, vol. 51, pp. 421-425, 1987.

[14] F. R. Noss, H. B. Quigley, M. G. Hornocker, T. Merrill, and P. C. Paquet, "Conservation biology and carnivore conservation in 
the Rocky Mountains," Conservation Biology, vol. 10, pp. 949 963, 1996.

[15] L. J. Petit and D. R. Petit, "Factors governing habitat selection by prothonotary warblers: field tests of the fretwell-lucas models 1," Ecological Monographs, vol. 66, no. 3, pp. 367-387, 1996.

[16] L. W. Bruinzeel, "Intermittent breeding as a cost of site fidelity," Behavioral Ecology and Sociobiology, vol. 61, no. 4, pp. 551-556, 2007.

[17] J. Da Silva, D. W. Macdonald, and P. G. H. Evans, "Net costs of group living in a solitary forager, the Eurasian badger (Meles meles)," Behavioral Ecology, vol. 5, no. 2, pp. 151-158, 1994.

[18] B. Keane, P. M. Waser, S. R. Creel, N. M. Creel, L. F. Elliott, and D. J. Minchella, "Subordinate reproduction in dwarf mongooses," Animal Behaviour, vol. 47, no. 1, pp. 65-75, 1994.

[19] M. A. Cant, "Social control of reproduction in banded mongooses," Animal Behaviour, vol. 59, no. 1, pp. 147-158, 2000.

[20] T. H. Clutton-Brock, "Mammalian mating systems," Proceedings of the Royal Society B., vol. 236, no. 1285, pp. 339-372, 1989.

[21] E. J. Comiskey, O. L. Bass Jr., L. J. Gross, R. T. McBride, and R. Salinas, "Panthers and forests in South Florida: an ecological perspective," Conservation Ecology, vol. 6, no. 1, p. 18, 2002.

[22] R. A. Powell, "Mustelid spacing patterns, variations on a theme by Mustela," Zeitschrift für Tierpsychologie, vol. 50, pp. 153$165,1979$.

[23] M. G. Hornocker, J. P. Messick, and W. E. Melquist, "Spatial strategies in three species of Mustelidae," Acta Zoologica Fennica, vol. 174, pp. 185-188, 1983.

[24] T. Lodé, "Conspecific tolerance and sexual segregation in the use of space and habitats in the European polecat," Acta Theriologica, vol. 41, no. 2, pp. 171-176, 1996.

[25] P. Genovesi, I. Sinibaidi, and L. Boitani, "Spacing patterns and territoriality of the stone marten," Canadian Journal of Zoology, vol. 75, no. 12, pp. 1966-1971, 1997.

[26] S. D. Gehrt and E. K. Fritzell, "Behavioural aspects of the raccoon mating system: determinants of consortship success," Animal Behaviour, vol. 57, no. 3, pp. 593-601, 1999.

[27] T. Lodé, "Mating system and genetic variance in a polygynous mustelid, the European polecat," Genes and Genetic Systems, vol. 76, no. 4, pp. 221-227, 2001.

[28] T. B. Poole, "Detailed analysis of fighting in polecats using cine film," Journal of Zoology, vol. 173, pp. 396-393, 1974.

[29] T. Lodé, "Activity pattern of polecats Mustela putorius L. in relation to food habits and prey activity," Ethology, vol. 100, no. 4, pp. 295-308, 1995.

[30] E. H. Simpson, "Measurement of diversity," Nature, vol. 163, no. 4148 , p. $688,1949$.

[31] T. G. Whitham, "The theory of habitat selection, examined and extended using Pemphigus aphids," American Naturalist, vol. 115, pp. 449-466, 1980.

[32] S. Kurki, A. Nikula, P. Helle, and H. Lindén, "Abundances of red fox and pine marten in relation to the composition of boreal forest landscapes," Journal of Animal Ecology, vol. 67, no. 6, pp. 874-886, 1998.

[33] M. Camp and L. B. Best, "Nest density and nesting success of birds in roadsides adjacent to rowcrop fields," American Midland Naturalist, vol. 131, no. 2, pp. 347-358, 1994.

[34] J. J. Kolbe and F. J. Janzen, "Impact of nest-site selection on nest success and nest temperature in natural and disturbed habitats," Ecology, vol. 83, no. 1, pp. 269-281, 2002.

[35] Y. Haila, A. O. Nicholls, I. K. Hanski, and S. Raivio, "Stochasticity in bird habitat selection: year-to-year changes in territory locations in a boreal forest bird assemblage," Oikos, vol. 76, no. 3, pp. 536-552, 1996.

[36] L. S. Durbin, "Habitat selection by five otters Lutra lutra in rivers of northern Scotland," Journal of Zoology, vol. 245, no. 1, pp. 85-92, 1998.

[37] B. W. Compton, J. M. Rhymer, and M. McCollough, "Habitat selection by wood turtles (Clemmys insculpta): an application of paired logistic regression," Ecology, vol. 83, no. 3, pp. 833$843,2002$.

[38] A. Bifolchi and T. Lodé, "Efficiency of conservation shortcuts, a test with European otter as umbrella species for biodiversity preservation," Biological Conservation, vol. 126, pp. 523-527, 2005.

[39] E. Virgós and J. G. Casanovas, "Distribution patterns of the Stone marten (Martes foina Erxleben, 1777) in Mediterranean mountains of central Spain," Zeitschrift fur Saugetierkunde, vol. 63, no. 4, pp. 193-199, 1998.

[40] J. Zabala, I. Zuberogoitia, I. Garin, and J. Aihartza, "Landscape features in the habitat selection of European mink (Mustela lutreola) in south-western Europe," Journal of Zoology, vol. 260, no. 4, pp. 415-421, 2003.

[41] A. L. Lyons, W. L. Gaines, and C. Servheen, "Black bear resource selection in the northeast Cascades, Washington," Biological Conservation, vol. 113, no. 1, pp. 55-62, 2003.

[42] W. D. Spencer, R. H. Barrette, and W. J. Zielinski, "Marten habitat preferences in the northern Sierra Nevada," Journal of Wildlife Management, vol. 47, pp. 1181-1186, 1983.

[43] A. Zalewski and W. Jedrzejewski, "Spatial organisation and dynamics of the pine marten Martes martespopulation in Bial owiezÿa Forest E Poland compared with other European woodlands," Ecography, vol. 29, pp. 31-43, 2006.

[44] W. Jedrzejewski, K. Schmidt, J. Theuerkauf, B. Jedrzejewska, and R. Kowalczyk, "Territory size of wolves Canis lupus, linking local Bialowiezÿa Primeval Forest, Poland and Holarcticscale patterns," Ecography, vol. 30, pp. 66-76, 2007.

[45] T. Lodé, "Trophic status and feeding habits of the European Polecat Mustela putorius L. 1758," Mammal Review, vol. 27, no. 4, pp. 177-184, 1997.

[46] T. Lodé, "Functional response and area-restricted search in a predator: seasonal exploitation of anurans by the European polecat, Mustela putorius," Austral Ecology, vol. 25, no. 3, pp. 223-231, 2000.

[47] T. Lodé, "Genetic divergence without spatial isolation in polecat Mustela putorius populations," Journal of Evolutionary Biology, vol. 14, no. 2, pp. 228-236, 2001.

[48] S. Larivière and F. Messier, "Spatial organization of a prairie striped skunk population during the waterfowl nesting season," Journal of Wildlife Management, vol. 62, no. 1, pp. 199204, 1998.

[49] R. B. Wielgus and F. L. Bunnell, "Tests of hypotheses for sexual segregation in grizzly bears," Journal of Wildlife Management, vol. 59, no. 3, pp. 552-560, 1995.

[50] T. Oksanen, L. Oksanen, and M. Norberg, "Habitat use of small mustelids in north Fennoscandian tundra: a test of the hypothesis of patchy exploitation ecosystems," Ecography, vol. 15, no. 2, pp. 237-244, 1992. 

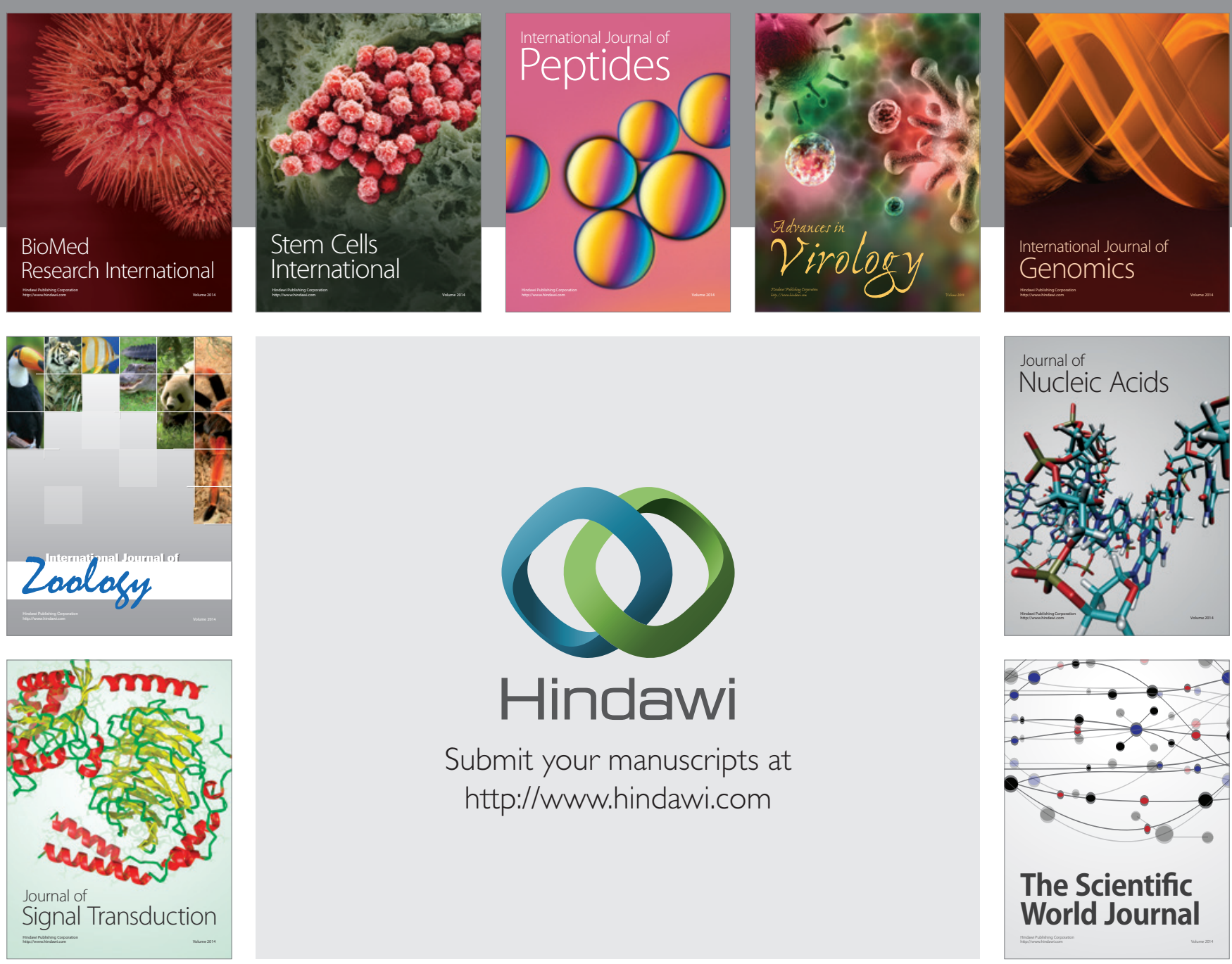

Submit your manuscripts at

http://www.hindawi.com
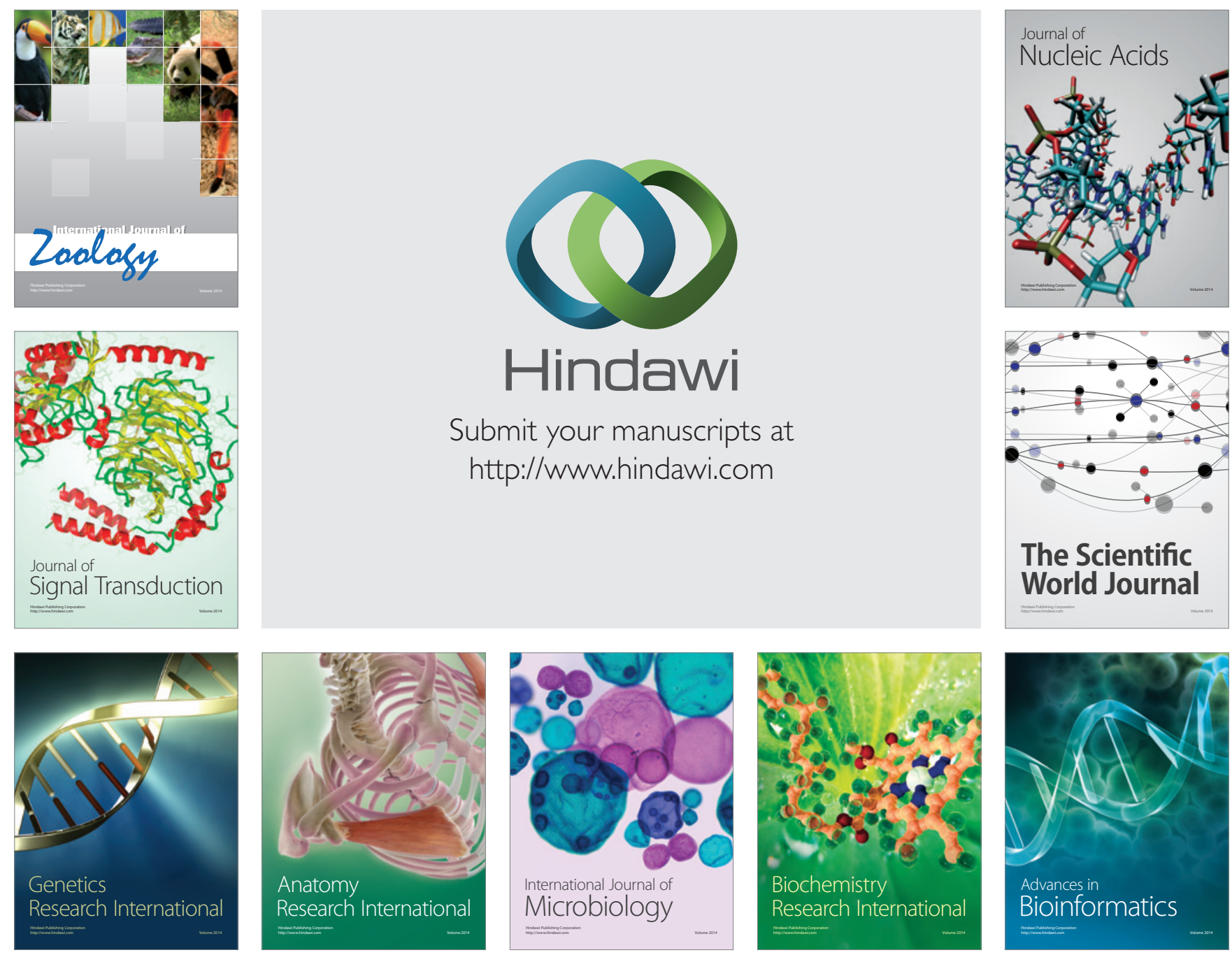

The Scientific World Journal
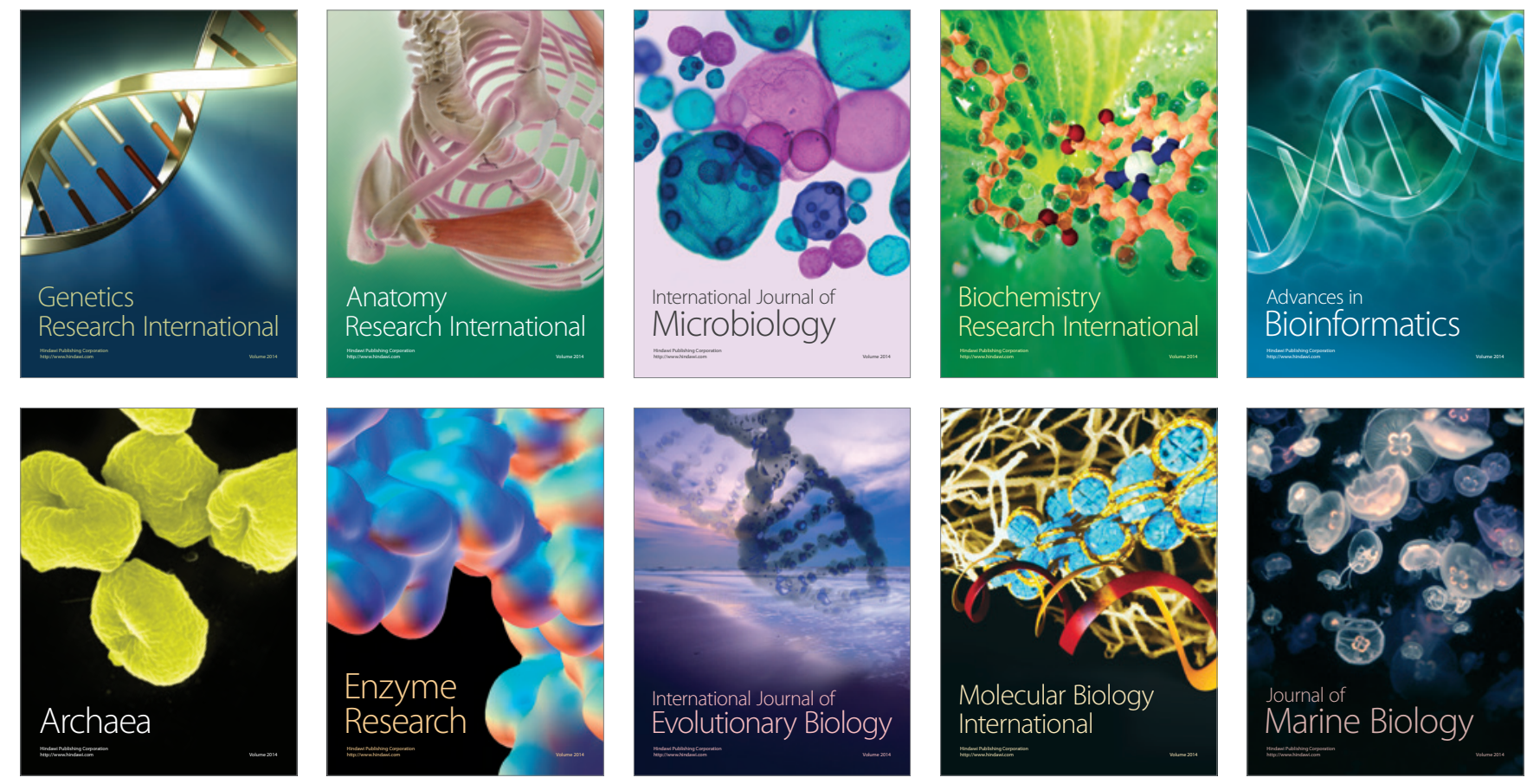